\title{
Recklessness: being reckless and acting recklessly
}

\section{Sally Cunningham}

\section{Abstract}

The case of $R v G$ may have consigned "objective" Caldwell recklessness to the history books, but this article argues that the development of two species of recklessness was necessitated through the law having to deal with risk-taking in two separate contexts: those of result crime and conduct crime. The mistake was for the law to try to apply a common meaning of recklessness (either subjective or objective) in both contexts. Instead, the law should have taken account of the different psychological processes involved, which entail that distinct forms of mens rea should be applied in each context.

\section{Introduction}

As a doctrine falling within the "general part" of the criminal law, the mens rea requirement of recklessness is one which has been the subject of much debate, both in academic texts and in the courts. This debate has largely centred on the subjective / objective ${ }^{1}$

\footnotetext{
${ }^{1}$ The terms "subjective" and "objective" are used here for the sake of convenience and simplicity. Although Lord Diplock, in Caldwell, criticised the use of such terms in describing different meanings of recklessness, it has become common for the test in Cunningham to be described as "subjective" (the defendant himself must have foreseen the risk) and the tests in Caldwell and Lawrence to be described as "objective" (the defendant must have created an obvious risk, although he himself need not have foreseen it). The Caldwell test still requires an element of subjectivity, however, since the court is asked to consider whether the defendant himself either identified it or gave no thought to its existence. Equally, the Cunningham test involves an element of objectivity, in that once it has been established that the defendant recognised the risk, he must have gone on to take it when it was unreasonable to do so.
} 
dichotomy, represented in the cases of Cunningham ${ }^{2}$ on the one hand, and Caldwell $^{3}$ and Lawrence $^{4}$ on the other. Whilst there are those that take an objectivist stance it is rare for the Caldwell/Lawrence definition of recklessness to be accepted outright, with commentators offering variations designed to avoid the weaknesses of the judicial approach, in the form of "practical indifference", "wilful blindness" 5 and so on. This article does not seek to add to suggestions redefining the requirements of recklessness but instead argues that although recklessness forms part of what is called the "general part" of the criminal law, this debate has arisen out of a misconceived presumption that recklessness, as a form of mens rea, should mean the same thing in relation to all offences.

The article will start by charting a brief history of the use of the term "recklessness" in the criminal law, demonstrating that the way in which it has been used has altered considerably over time, in part as a result of the need to cater for novel forms of blameworthy offending, particularly bad driving, as they arose. The suggestion that arises from this exploration of the origins of the use of the word is that it is not fit for purpose, or at least that it is not a "one size fits all" fit. The distinction that the law has so far failed to make in its use of recklessness is that in terms of thought processes it is entirely different to be reckless as to a specific consequence of one's actions, a consequence prohibited by the criminal law, and to engage in action which is in itself reckless in that it creates a risk of an undesired harmful

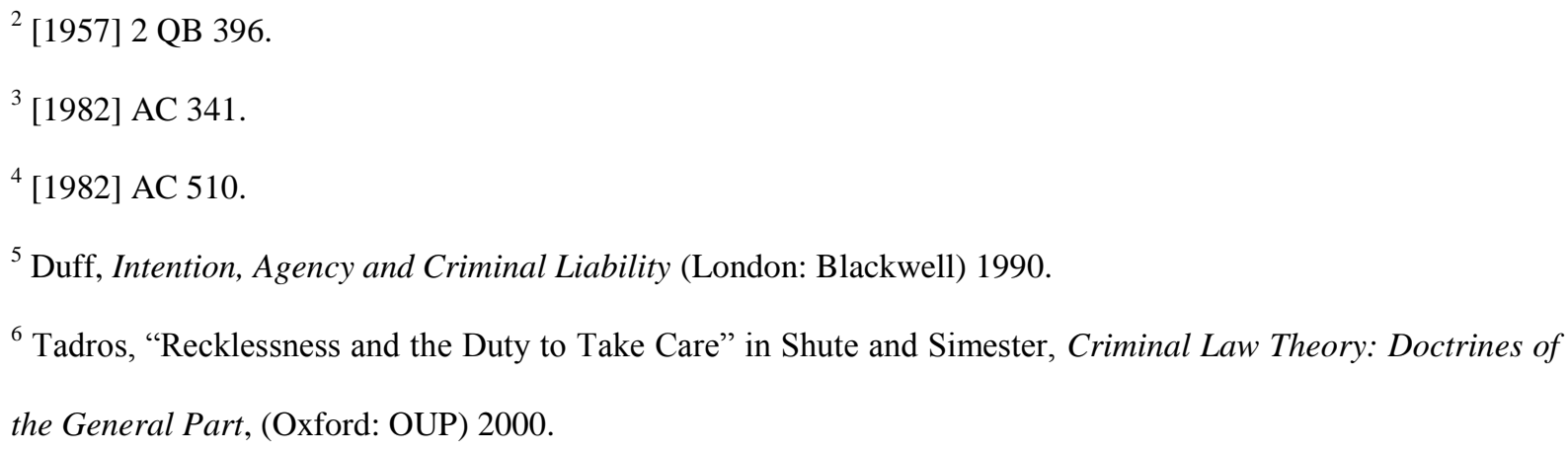


outcome which might arise if the action is continued, which leads the law to criminalise such action with the aim of preventing such harm. One could take the view that recklessness ought to mean different things in relation to result crimes and conduct crimes. Ultimately it is submitted that the label of "recklessness" should never have been utilised in its objective form in relation to conduct crimes, and that "gross negligence" is preferable.

\section{The historical development of recklessness}

Halpin acknowledges that the "historical context" of recklessness might be a useful exercise in discovering if different concepts of recklessness were introduced in relation to different offences (for example criminal damage and driving offences), although it is something which he states is not of interest to him. ${ }^{7}$ For Norrie, on the other hand, the historical development of recklessness is entirely appropriate in explaining how, but more importantly why, we find ourselves with two opposing interpretations of recklessness: "The law's subjectivist/objectivist division ... is the historical product of the de-moralisation and decontextualisation of fault that occurred through the Enlightenment reform project. It was not an inevitable consequence of any process of legal judgment, but the actual product of a control process informed by liberal principle in a social order in conflict." ${ }^{\text {It }}$ is not, however, proposed that a detailed blow-by-blow account of the development of the law is needed here ${ }^{9}$ it will be sufficient to note that the law has developed along two separate, parallel trajectories, with the difficulties arising once the two paths collided. During much of the

\footnotetext{
${ }^{7}$ Halpin, Definition in the Criminal Law (Oxford: Hart) 2004, p.107.

${ }^{8}$ Norrie, Crime, Reason and History, 2nd ed. (London: Butterworths) 2001, p.60.

${ }^{9}$ For a more detailed account of the law of recklessness from the 1830 s to 1957 see Smith, K.J.M., Lawyers, Legislators and Theorists: Developments in English Criminal Jurisprudence 1800-1957 (Oxford: Clarendon
} Press) 1998. 
twentieth century it would appear that recklessness was developing as a doctrine of mens rea both as an interpretation of "malice" and as a substitute for "negligence".

\section{1. "Recklessness" defined in terms of "negligence"}

"Reckless" was first used in the determination of blameworthiness in criminal cases as an epithet in relation to the degree of negligence required to find a defendant guilty of manslaughter. During the nineteenth century Smith notes that there was an absence of uniformity in judicial directions on the nature and quality of negligence required for conviction for manslaughter. ${ }^{10}$ Negligence simpliciter was clearly not enough to warrant conviction for such a serious offence as manslaughter, but the difficulty was in determining how bad the negligence must be before conviction was warranted.

A related issue was the question of whether an objective test ought to apply, requiring D to live up to a particular standard, or whether D could avoid liability as long as he did his incompetent best. ${ }^{11}$ This can be seen in the case of Williamson, ${ }^{12}$ where an untrained "manmidwife" who attempted to assist the deceased to give birth escaped liability for her death because there was no evidence of inattention on his part. To put it crudely, he had merely bitten off more than he could chew. Smith notes that by the 1830's the wisdom of taking such an approach started to come into question, and a more objective test requiring $\mathrm{D}$ to display a certain degree of skill before engaging in dangerous operations started to be introduced. ${ }^{13}$

\footnotetext{
${ }^{10}$ Ibid, p. 193.

${ }^{11}$ Ibid, p.89.

12 (1807) 3 C \& P 635.

${ }^{13}$ Smith, above n.9, p.89.
} 
Once it became established that those who engaged in medical practices were required to be skilled in such procedures, the question remained as to how bad the defendant's conduct must be before he would be convicted of manslaughter. Some cases merely suggested that the degree of negligence needed was something above the level of that required for civil liability, ${ }^{14}$ whilst others tried to express the degree of negligence required as an adjective. It is in this context that "recklessly" was used in the case of Elliott. ${ }^{15}$

The first occasion on which the word "reckless" or "recklessly" was attached to the definition of a statutory offence within English law was in the Motor Car Act 1903, ${ }^{16}$ s.1(1) of which read:

If any person drives a motor car on a public highway recklessly or negligently, or at a speed or in a manner which is dangerous to the public, having regard to all the circumstances of the case, including the nature, condition and use of the highway, and to the amount of traffic which actually is at the time, or which might reasonably be expected to be, on the highway, that person shall be guilty of an offence under this Act.

This section actually introduced four offences, one of which was reckless driving. ${ }^{17}$ Prior to the enactment of this offence, drivers of motor vehicles could be prosecuted for

\footnotetext{
${ }^{14}$ Ibid. Smith cites such cases as Doherty (1887) 16 Cox 544 and Finney (1874) 12 Cox 625.

15 (1889) 16 Cox 79.

${ }^{16}$ Reid (1992) 95 Cr App R 391 at 403.

${ }^{17} R v$ Jones, ex parte Thomas [1921] $1 \mathrm{~KB} 632$. The other three offences were driving negligently, driving at a speed which is dangerous to the public and driving in a manner which is dangerous to the public.
} 
offences originally designed for drivers of horses and carriages, such as "furious" driving. ${ }^{18}$ Due to the greater speeds which could be achieved by a motor car, it was seen to be necessary to introduce a separate law for such vehicles. In passing this new law there was some discussion in the House of Lords as to whether the words "without due care" should be used instead of "negligently", ${ }^{19}$ but it would appear that little consideration was given to the suitability of the word "recklessly" in this context, which was adopted with limited discussion. $^{20}$

${ }^{18}$ Offences Against the Person Act 1861, s.35 - "Whosoever having the charge of any carriage or vehicle, shall, by wanton and furious driving or racing, or other wilful misconduct, or by wilful neglect, do or cause to be done any bodily harm to any person whatsoever, shall be guilty of an offence." Note that this requires that bodily harm is caused. The Highway Act 1835, s.78 included offences of causing hurt or damage to any person by negligence or wilful misbehaviour, negligently or wilfully being at such a distance from a carriage so as not to have direction and government of the horses and driving furiously so as to endanger life or limb. Another offence of "wanton and furious" driving, and other offences, applies specifically to the driver of Hackney carriages under London Hackney Carriages Act 1843, s.28.

${ }^{19}$ Hansard, 24 July 1903, vol 25, col 213.

${ }^{20}$ One MP in the House of Commons was of the opinion that the use of this word, rather than the one already in use of "furiously", did nothing to change the substance of the law, and argued that the new law merely placed the motor car driver in the same position as the "ordinary" driver: Mr Cripps, MP for Stretford: Hansard, 4 August 1903, vol 26, col 1476. Smith states that the parliamentary debates "display a mixture of confusion and indifference over the nature and quality of 'recklessness'. The general tenor of discussion strongly suggests the term to have an objective fault meaning": Smith, above n.9, p.286 (in footnote 36). There are very few early cases on reckless driving. In Troughton v. Manning [1905] 26 LT 855 the issue was whether a driver could be convicted of reckless driving when he had driven in a way which caused no danger to anyone other than the respondent, who had jumped onto the side of the vehicle. Kennedy J. said that he thought the intention of s.1 Motor Car Act 1903 was to "prevent misconduct in the management of a motor car towards the public who were 
Writing in 1933, Turner commented on the successor of s.1 Motor Car Act 1903, s.11 of the Road Traffic Act 1930, that: "It is hard to see what 'reckless' can mean except 'realizing the possibility of harm to others".. ${ }^{21}$ By that time the statutory provision had lost the term "or negligently" but Turner was not clear as to whether "reckless" driving and "dangerous driving" were two separate offences or whether the words "at a speed or in a manner which is dangerous, etc." were explanatory of the word "recklessly". 22 Whilst Turner was at that time fully committed to the view that mens rea could only include intention or (subjective) recklessness, Kenny had, in his book Outlines of Criminal Law, divided fault into intention, recklessness and negligence. ${ }^{23}$

What appears surprising is that the legislature in 1930 decided to discard the term "negligently" from the statutory offence and preserve "recklessly", given that gross negligence was the mens rea term in use to establish liability for manslaughter in cases of fatal traffic collisions. However, as noted above, there was no agreement as to whether "gross" was the best adjective to use in describing the degree of negligence required for manslaughter, and "recklessly negligent" had been used in the case of Elliott. The explanation for the legislature's disposal of the term "negligently" in the Road Traffic Act 1930 can probably be attributed to the development of case law, since by then "recklessly"

outside it on the highway. The section was not meant for the protection of persons on the car itself... I do not think that the intention was to punish anyone who was reckless as regards passengers on the car". It seems that the court was clear on what should not be included within reckless driving, but gave no indication of what should be.

\footnotetext{
${ }^{21}$ Turner, "Mens Rea and Motorists" (1933) 5 CLJ 61, at 75.

${ }^{22}$ Ibid.

${ }^{23}$ Smith, above n.9, p.292.
} 
and "negligently" were frequently used in tandem or synonymously. ${ }^{24}$ Indeed, shortly before the 1930 Act was passed Lord Hewart in Bateman ${ }^{25}$ had used the word "recklessness" in describing a medical practitioner who took on a case which he knew, or ought to have known, was beyond his powers, whilst at the same time laying down the infamous test that the blameworthiness required for conviction for manslaughter was that of negligence of an order that "went beyond a mere matter of compensation between subjects and showed such disregard for the life and safety of others as to amount to a crime against the State and conduct deserving punishment." 26

Following the enactment of the Road Traffic Act 1930 this question of the degree of negligence required for conviction for manslaughter was again addressed in Andrews $v$ $D P P{ }^{27}$ This case saw the two areas of law using "recklessly" as a substitute for "negligence" combined in a case which dealt with the issue of how a driver could be convicted of manslaughter. At this stage, on the face of it at least, the problem of how to deal with drivers who kill seems to have been tackled with little difficulty. Lord Atkin concluded that the general rule applicable to all charges of manslaughter by negligence ${ }^{28}$ should also apply to cases of motor manslaughter and considered the appropriateness of "reckless" in describing the degree of negligence required:

[p]robably of all the epithets that can be applied 'reckless' most nearly covers the case... but it is probably not all embracing, for 'reckless' suggests an indifference

\footnotetext{
${ }^{24}$ Ibid, p.282.

25 (1925) 19 Cr.App.R. 8.

${ }^{26} \mathrm{Ibid}$, at $11-12$.

${ }^{27}$ [1937] AC 576.

${ }^{28}$ As laid down in the case of Bateman (1925) 19 Cr App R 8.
} 
to risk whereas the accused may have appreciated the risk and intended to avoid it and yet shown such a high degree of negligence in the means adopted to avoid the risk as would justify conviction. ${ }^{29}$

In doing so, Lord Atkin compounded confusion over the meaning of negligence, such confusion being perpetuated in later cases. ${ }^{30}$ Smith notes, however, that the majority of cases were in agreement that criminal negligence "was the failure to achieve the objectively appropriate standard of behaviour in any given situation whether, for instance, driving or acting as a medical practitioner". ${ }^{31}$ However, confusion has endured and been revitalised by Lord Mackay in Adomako 32 endorsing Lord Atkin's use of the word "reckless". Given that under current law subjective recklessness arguably remains in existence alongside gross negligence manslaughter, ${ }^{33}$ it is not clear that Lord Atkin's use of the term is helpful in any way and can only make matters worse.

It was not until "dangerous" driving was abolished in the Criminal Law Act 1977 that judicial attention was drawn to the need to consider the appropriate definition of "reckless" in the offence of reckless driving, ${ }^{34}$ when in Murphy ${ }^{35}$ the court decided that "reckless" in

${ }^{29}$ At p.583.

${ }^{30}$ Smith, above n.9, p.282.

${ }^{31}$ Smith, above n.9, p.284.

${ }^{32}$ [1995] 1 AC 171.

${ }^{33}$ Clarkson, Keating and Cunningham, Clarkson and Keating Criminal Law: Text and Materials $6^{\text {th }}$ ed. (London: Sweet and Maxwell) 2007, p.687.

${ }^{34}$ As Lord Diplock explained in the case of Lawrence (at 523) although the word "recklessly" had appeared in statutes since 1903, after 1930 when careless driving was introduced it had been the practice to charge 
relation to driving meant "heedlessly rash" or indifferent to risk in the sense of not caring whether there is a risk or not, which may consist in the very failure to recognise obvious risks. This must be the case, the court concluded, otherwise in cases of driving "the rasher a defendant is the better his position in law might be". ${ }^{36}$

One other offence in relation to which the word "reckless" has been used as a substitute for negligence is that of child neglect under s.1 of the Children and Young Persons Act 1933. The House of Lords had the opportunity in the case of Sheppard ${ }^{37}$ to provide an interpretation of what is meant by "wilful neglect" under section 1. In doing so, those in the majority employed the word "reckless" in describing the state of mind required to convict parents of the offence. For example, Lord Edmund-Davies said:

A parent reckless about the state of his child's health, not caring whether or not he is at risk, cannot be heard to say that he never gave the matter a thought and was therefore not wilful in not calling in a doctor. In such circumstances recklessness constitutes mens rea no less than positive awareness of the risk involved in failure to act. $^{38}$

Elsewhere in statute, the term "reckless" has been used as a substitute for "negligence" in relation to the offence of making a misleading forecast under s.12(1) of the defendants with driving "at a speed or in a manner which is dangerous to the public" and not with driving "recklessly".

${ }^{35}$ [1980] Q.B. 434.

${ }^{36} \mathrm{Ibid}$, at p.437.

37 (1981) 72 Cr App R 82.

${ }^{38} \mathrm{Ibid}$, at p.93. 
Prevention of Fraud (Investements) Act 1939. In the case of Bates, ${ }^{39}$ Donovan J. dealt with the question of whether the "reckless making of any statement, promise or forecast which is misleading, false or deceptive" under s.12(1) was required to be dishonest. He held that Parliament must have meant for "reckless" to be construed as covering the case where there is a high degree of negligence without dishonesty, so that even the honest forecaster should take due care to see that his forecast was not misleading, false and deceptive, or face criminal punishment. ${ }^{40}$ In coming to that conclusion he drew on the "ordinary meaning" of the word "reckless" in the English language as: "“careless', 'heedless', 'inattentive to duty'. Literally, of course, it means 'without reck'. 'Reck' is simply an old English word, now, perhaps, obsolete, meaning 'heed', 'concern', or 'care". ${ }^{41}$ Donovan J. was clearly of the opinion that reckless in this context meant gross negligence, although he chose to express this in terms of the defendant displaying a "high degree" of negligence.

\section{2. "Recklessness" as an interpretation of "malice"}

Over time it seems that "reckless" became used as an interpretation of "malice" which had been a mens rea requirement of several statutory offences. ${ }^{42}$ Many of these offences survive today, such as malicious wounding under the Offences Against the Person Act $1861,{ }^{43}$ but others, such as offences under the Malicious Damage Act 1861, have since been

39 (1952) 36 Cr. App. R. 175.

${ }^{40} \mathrm{Ibid}$, at 182 .

${ }^{41}$ Ibid. at 181 .

${ }^{42}$ At common law malice has carried various different meanings, particularly in relation homicide. See: Horder, “Two Histories and Four Hidden Principles of Mens Rea” [1997] 113 LQR 95. This discussion will be confined to "malice" in statute from the mid-nineteenth century onwards.

${ }^{43}$ s. 20. 
replaced. This development commenced in the last quarter of the nineteenth century, in cases such as Pembliton, ${ }^{44}$ and Welch ${ }^{45}$ and by the case of Martin ${ }^{46}$ Smith states that "recklessness" was "increasingly assuming a meaning of conscious risk taking". ${ }^{47}$ The judges using the term seem not to have considered the need for a clear definition of it; such definition did not appear until the beginning of the twentieth century and has been accredited to Professor Kenny. Kenny's definition of malice, which originally appeared in 1902 but continued to be referred to in later editions of his book edited by Turner, was that:

In any statutory definition of a crime, malice must be taken not in the old vague sense of wickedness in general but as requiring either (1) An actual intention to do the particular kind of harm that in fact was done; or (2) recklessness as to whether such harm should occur or not (i.e., the accused has foreseen that the particular kind of harm might be done and yet has gone on to take the risk of it). ${ }^{48}$

44 (1874) 2 C.C.R. 119. Here the offence alleged was one of unlawfully and maliciously breaking a window under s.51 of the 1861 Act. Smith notes that Blackburn J seems to have used "reckless" in the subjective sense in that he said that D's act would be malicious if D knew the natural consequences of his act would be to break the glass, although that was not his wish, and he was reckless whether he did it or not. However, Lord Coleridge $\mathrm{CJ}$ in the same judgment combined his use of the word "reckless" with "reasonably", seemingly mixing subjective and objective fault elements. Smith, above n.9, p.164.

${ }^{45}$ (1875) 1 QB 23.

${ }^{46}(1881) 8$ QB 54.

${ }^{47}$ Smith, above n.9, p. 165 .

${ }^{48}$ Turner, Kenny's Outlines of Criminal Law, $19^{\text {th }}$ ed., 1966, Cambridge University Press,, para.158a. This is the definition of malice attributed to Kenny by the Court of Appeal in Cunningham. Note, however, that Horder suggests that this is not Kenny's original definition, and attacks Turner's definition as paraphrasing Kenny in a 
Kenny's explanation of the meaning of recklessness in the context of crimes requiring malice was officially endorsed in the Court of Appeal's judgment in Cunningham, ${ }^{49}$ a case of maliciously administering a noxious thing, ${ }^{50}$ and was also adopted in relation to malicious wounding ${ }^{51}$ and assault. ${ }^{52}$ For some time the law seems to have worked fairly satisfactorily, using the Cunningham test of recklessness in relation to offences requiring malice, such as non-fatal offences against the person and offences punishing damage to property. In relation to the latter offence it was thought necessary to modernise the law and so the Criminal Damage Act 1971 amended the statutory requirement of "malicious" criminal damage to a requirement of "recklessness".

\section{The two paths collide: Caldwell and Lawrence}

The fact that recklessness was used to interpret the meaning of malice in case law explains why, when the legislature came to modernise the law of criminal damage, it chose to replace the statutory requirement of "malicious" criminal damage with a requirement of

misleading way. He criticises the Court of Appeal in Cunningham for not paying closer attention to what Kenny himself said, suggesting that Cunningham should not be regarded as a landmark in legal thinking about the meaning of malice: Horder, above n.34, pp.114-118.

${ }^{49}$ [1957] 2 QB 396.

${ }^{50}$ Offences Against the Person Act 1861, s.23.

${ }^{51}$ Under Offences Against the Person Act 1861, s.20 in Mowatt [1968] 1 QB 421.

${ }^{52}$ Including assault occasioning actual bodily harm under Offences Against the Person Act 1861, s.47, in Venna [1976] Q.B. 421. 
"recklessness". ${ }^{53}$ However, it was shortly after this that the real problems with the definition of recklessness began to arise.

When the Criminal Damage Act was first passed, the courts' interpretation of the word "reckless" in section 1 of the statute was the same as that adopted in Cunningham. This had been the wishes of the Law Commission, who had wanted the word "maliciously" to be avoided, ${ }^{54}$ and whose proposed definition of recklessness mirrored the test given in Cunningham. ${ }^{55}$ The exact test was not initially clear, however, with the courts suggesting variations of the Cunningham test. The Court of Appeal in Stephenson ${ }^{56}$ confirmed that it was not enough that the risk would have been obvious to anyone in his right mind in the position of the defendant but that the defendant himself must have foreseen the risk. ${ }^{57}$

${ }^{53}$ Although Lord Diplock, in Caldwell, was at pains to suggest that Kenny's interpretation of recklessness given in his definition of malice was just one of a range of alternative available meanings to be given to recklessness and there was nothing to suggest that "reckless" in s.1 Criminal Damage Act 1971 should use this meaning: [1982] A.C. 341 at 351. In fact there was something to suggest that "reckless" in s.1 of the Act should use this meaning: the Law Commission's Working Paper which made it clear that the meaning attributed to "reckless" should apply to a new criminal damage offence, and that "malicious" should be avoided because it was technical, confusing and unhelpful: Law Commission Working Paper no.23, Malicious Damage, 1969.

${ }^{54}$ Law Commission Report No.29, Report on Offences of Damage to Property, 1970, para.44.

${ }^{55}$ Law Commission Working Paper No.31, General Principles: The Mental Element in Crime, 1970. ${ }^{56}$ [1979] 1 Q.B. 695.

57 Prior to Stephenson, the same court had held in Briggs (1976) 63 Cr. App. R. 215 that a subjective test applied, in that a man is reckless in causing criminal damage when "he carries out a deliberate act knowing that there is some risk of damage resulting from that act but nevertheless continues in the performance of that act" (at 218). However, this definition had been altered slightly in the case of Parker (1976) 63 Cr. App. R. 211, with the addition of the words "or closing his mind to the obvious fact" (at 214). It was suggested that this introduced 
It will be remembered that an objective test of recklessness was applied to the offence of reckless driving in Murphy in the early 1980's. In that case the appellant's argument had been that "recklessness" carried a subjective meaning, as confirmed in cases relating to criminal damage. The Court of Appeal, however, agreed with the view of the Crown that reckless driving did not necessitate adopting the meaning of "reckless" used for the crime of criminal damage. If the courts had chosen to keep separate the two paths that recklessness had followed up until this point, the law might not have got itself into the difficulties it found itself in during the 1980's and 1990's until $R v G^{58}$ was decided. However, unfortunately from this point forward the line drawn between the two became blurred, and the law in relation to criminal damage became infected by an objective standard originally used in relation to manslaughter cases and adopted for the purposes of the driving offence.

In Caldwell, Lord Diplock decided to force open the door that had been left ajar by Parker $^{59}$ but slammed shut in Stephenson, by reformulating the test for recklessness required for criminal damage. He was keen to undermine the distinction given by many of "subjective" versus "objective" tests, but the test that he propounded is often referred to as the objective test for recklessness. This was that:

A person charged with an offence under section 1(1) of the Criminal Damage Act 1971 is 'reckless as to whether any such property would be destroyed or damaged' if (1) he does an act which in fact creates an obvious risk that an objective test, which was the basis upon which Stephenson was originally convicted, but in the latter case the Court of Appeal held that the test remained subjective.

58 [2003] UKHL 50.

59 (1976) 63 Cr. App. R. 211. 
property will be destroyed or damaged and (2) when he does the act he either had not given any thought to the possibility of there being any such risk or has recognised that there was some risk involved and has nonetheless gone on to do it. $^{60}$

Lord Bingham later suggested that the reason for the adoption of the objective test in this case was that the case was complicated by the issue of self-induced intoxication, ${ }^{61}$ and so it might have been that without this element to the case Stephenson would not have been overruled. On the same day that Caldwell was decided, however, the House of Lords also handed down a judgment on the meaning of the word "reckless" in relation to reckless driving in the case of Lawrence. In Lawrence the appellant had been convicted of causing death by reckless driving after the trial judge had directed the jury in accordance with Murphy. ${ }^{62}$ In overruling Murphy Lord Diplock's main reasoning seems to have been that it failed to distinguish reckless driving from careless driving and he adopted his own test for recklessness in Caldwell, amending it slightly to require a driver to have driven in such a manner as to create an obvious and serious risk of causing physical injury to some other person or of doing substantial damage to property. ${ }^{63}$

\footnotetext{
${ }^{60}$ [1982] A.C. 341 at 354.

${ }^{61}$ In $R v G$, above n.58 at [36].

${ }^{62}$ Eveleigh LJ laid down the following test for reckless driving in Murphy (at 440): “A driver is guilty of driving recklessly if he deliberately disregards the obligation to drive with due care and attention or is indifferent as to whether or not he does so and thereby creates a risk of an accident which a driver driving with due care and attention would not create."

${ }^{63}$ At p.526.
} 
From there the new objective test was applied to manslaughter in Seymour ${ }^{64}$ where a driver had been charged with manslaughter. The trial judge directed the jury in accordance with the test in Lawrence and D was convicted and appealed on the basis that whilst recklessness under the Lawrence test was proof of guilt of causing death by reckless driving, a different test of gross negligence was required for manslaughter according to Andrews. The House of Lords disagreed, Lord Roskill stating that since he had decided in $R v$ Governor of Holloway Prison, ex $p$ Jennings $^{65}$ that the ingredients of the statutory offence of causing death by reckless driving and the common law offence were the same and that both required the mens rea of recklessness, the same meaning should be given to "recklessness".

The objective test was confirmed as being applicable to criminal damage in the case of Elliott v. $C,{ }^{66}$ decided in the Divisional Court. It was clear that Goff LJ disagreed with the strict application of the objective test with the result that a child who was incapable of recognising the risk was liable (although he felt bound by it). It is not inconsistent that the same judge should support the use of an entirely objective test in relation to reckless driving, however, as he did in Reid, since the nature of the offences are quite different, as will be argued below. It was not until $R v G$ that the House of Lords felt able to turn the tide and overrule the interpretation of recklessness applied to criminal damage in Caldwell.

In $\operatorname{Reid},{ }^{67}$ a case of causing death by reckless driving, the House of Lords again confirmed that Lawrence was correctly decided. The irony of the case is that by the time the

\footnotetext{
${ }^{64}[1983] 2$ A.C. 493.

${ }^{65}$ [1983] 1 A.C. 624.

66 (1983) 77 Cr. App. R. 103.

${ }^{67}$ (1992) 95 Cr App R 391.
} 
House of Lords delivered its judgment the offences of reckless driving and causing death by reckless driving no longer existed, having been replaced by dangerous driving and causing death by dangerous driving under the Road Traffic Act $1991 .^{68}$ This renders much of the judgment in Reid academic. However, the House did depart slightly from what had been said before. The three judges who gave speeches all expressed the opinion that the word "reckless" does not necessarily bear exactly the same meaning in all statutes. ${ }^{69}$

Objective Caldwell/Lawrence recklessness was disapplied to manslaughter almost a decade before the House of Lords made its decision in relation to criminal damage in $R v G$. In Prentice ${ }^{70}$ the essential question for the Court of Appeal was whether gross negligence manslaughter had survived Caldwell and Lawrence. This question was answered in the affirmative, with Lord Taylor of Gosforth C.J. stating that the application of the Lawrence test to motor manslaughter in Seymour came about for historical reasons flowing from the coexistence of the common law and statutory offence of causing death by reckless driving. ${ }^{71}$ The Court of Appeal in Prentice held that except in cases of motor manslaughter, involuntary manslaughter by breach of duty required the jury to apply a test of gross negligence. The House of Lords upheld this decision on appeal in the case of Adomako, ${ }^{72}$ although it held that the test of gross negligence applied to all types of manslaughter by breach of duty, including motor manslaughter. Seymour was overruled on the basis that the underlying statutory provisions on which it rested had been repealed in 1991.

\footnotetext{
${ }^{68}$ Amending the Road Traffic Act 1988.

${ }^{69}$ Lord Ackner at p.401; Lord Goff at p.403; Lord Browne-Wilkinson at p.412.

${ }^{70}$ [1994] Q.B. 302.

${ }^{71}$ At p.322.

${ }^{72}$ Above n.32.
} 
By the mid-1990's objective Caldwell/Lawrence recklessness no longer applied to manslaughter and the offence of reckless driving had been repealed. In Coles $^{73}$ the Court of Appeal confirmed that the test for recklessness in relation to criminal damage remained that laid down in Caldwell, which does not make allowances for defendants who do not have the capacity to appreciate the risk they have created. However, the obvious injustice of this rule finally led to a change in the law in the case of $R v G .^{74}$ Lord Bingham stated that the majority in Caldwell had been wrong to ignore the authority of Cunningham, since there was nothing to suggest that Parliament had meant any other meaning to be attached to the word reckless. $^{75}$

\section{A key distinction: result crimes and conduct crimes}

The law has developed in the past century in such a way as to ground itself in a dichotomy of subjective versus objective recklessness. In relation to reckless driving, however, if the relevant statutes proscribing bad driving had stuck with the term "negligent" or "dangerous" and not, without proper consideration, employed the term "reckless", it may be that this dichotomy would never have taken hold. When the definition of "recklessness" in relation to reckless driving was eventually tackled by the courts it was necessary to consider how a driver's state of mind could be described as "reckless", informed by an understanding of the term derived from its use as a substitute for maliciousness, involving advertence to the risk. Lord Eveleigh attempted to grapple with this problem in Murphy:

\footnotetext{
${ }^{73}$ [1995] 1 Cr App R 157.

${ }^{74}$ Above, n.58.

${ }^{75}$ At [29].
} 
The direction, it is true, made no specific reference to a requirement that the driver should have appreciated and consciously rejected a risk, but it is arguable that to require knowledge that a risk was involved could imply that there should be a contemplation of the consequences of driving. Again when one speaks of something which a person knows, is one referring to knowledge which is stored in the brain and available if called upon or to knowledge which is actually present because it has been called upon? We do not think that Parliament in using the word in a straightforward way intended a meaning that would encourage such philosophical quibbles, especially as everybody knows that there is a risk of an accident if a vehicle is not driven with due care and attention on the highway, whether he thinks about it or not. ${ }^{76}$

The state of mind which Lord Eveleigh was attempting to describe is one that Duff has since labelled "latent knowledge" ${ }^{77}$ What is clear is that a driver who has latent knowledge that driving in a particular way may risk causing injury to others, and fails to call this knowledge to his conscious state of mind and use it as "actual" knowledge to inform the choices he makes when driving, is blameworthy in taking the risk. What is not clear, however, is that someone such as the defendant in Parker $^{78}$ who slams down a phone in a loss of temper, who clearly has the latent knowledge that doing so could cause damage to the phone but fails to bring this knowledge to the forefront of his mind at the time he acts, is sufficiently blameworthy to warrant conviction for non-aggravated criminal damage. This is because the two acts and the context in which they are carried out are quite different, and

\footnotetext{
${ }^{76}$ Above, n.35, at p 440 .

${ }^{77}$ Duff, "Caldwell and Lawrence: The Retreat from Subjectivism” (1983) 3 OJLS 77 at p.80.

${ }^{78}$ Above, n.59.
} 
involve disparate cognitive processes. That this is so indicates that they should be treated differently in law, as has been suggested in some of the cases looked at here.

The key to the mistakes made by the courts is that they tried to find a definition of recklessness to apply to both conduct crimes and result crimes. Reckless driving is a conduct crime. It does not require any concrete harm to have been caused by the blameworthy conduct of the offender, since it exists to punish those who take risks and to regulate the dangerous activity of driving. Non-aggravated criminal damage ${ }^{79}$ and offences against the person such as assault are result crimes which require a specific harm to have been caused as part of the actus reus of the offence. These two different types of crimes should have been dealt with in entirely different ways by the courts, given their different natures.

This distinction was recognised by some of those participating in the cases discussed earlier. In Murphy the distinction was made between "reckless" as an adjective describing an attitude towards certain possible consequences (result crime), and "recklessly" as an adverb governing the accused's conduct (conduct crime). In each case the word "reckless" or "recklessly" is doing a different job, and so it makes sense that it should carry a different meaning. In one, "recklessness" is describing a state of mind, whilst in the other it relates to the quality of D's act.

A similar argument was made in Lawrence. Counsel for the Crown contended that there are three basic categories of recklessness:

\footnotetext{
${ }^{79}$ From this point onwards the term "non-aggravated criminal damage" will be used to differentiate the offence under s.1(1) Criminal Damage Act 1971 from that under s.1(2) of the same Act.
} 
(a) Recklessness as to circumstance ('conduct crimes'). (b) Recklessness as to consequences ('result crimes') and (c) Recklessness as defined by statute in relation to a particular situation. ${ }^{80}$

Reckless driving falls within the first category (a), whilst non-aggravated criminal damage is an example of the second category (b). It would therefore be consistent to have two different tests such as those given in Murphy and Stephenson for different offences. In giving his judgment in Lawrence Lord Diplock did admit that there was a difference between the context in which the word "reckless" was used in relation to driving and in relation to criminal damage as the Crown had suggested, ${ }^{81}$ but went on to overrule Murphy and the test for recklessness therein contained for reckless driving. Following this, the suggested distinction between "reckless" as an adjective and "reckless" as an adverb was rejected explicitly by Lord Roskill in Jennings. ${ }^{82}$

The distinction between the adjective "reckless" and the adverb "recklessly" can be seen in the drafting of relevant legislation. Section 2 of the Road Traffic Act 1988, prior to amendment by the Road Traffic Act 1991, stated that: "a person who drives a motor vehicle on a road recklessly is guilty of an offence." This uses recklessly as an adverb in describing how a particular type of conduct which is normally lawful, can be proscribed if a person goes about the activity in a particular way. Section 1(1) of the Criminal Damage Act 1971 requires that $\mathrm{D}$ destroy or damage property belonging to another intending to do so or "being

\footnotetext{
${ }^{80}$ Above n.4, at p.514.

${ }^{81}$ Ibid at p.525.

${ }^{82}$ Above, n.65.
} 
reckless" as to doing so. "Reckless" describes D's state of mind when causing a proscribed harm, as an alternative to the state of mind of intention.

However, it is not the exact choice of wording in the drafting of statute which helps differentiate the way in which the term "reckless" should be interpreted. Section 1(2) of the Criminal Damage Act creates the aggravated form of the offence, committed by damaging property whilst intending or "being reckless" as to endangering the life of another. It is natural to assume that "being reckless" under s.1(1) and under s.1(2)(b) should mean the same thing. Under the above analysis they are both presented as a description of D's state of mind. However, it should be noted that the offence under s.1(2) is an endangerment offence incorporating a result crime within its construction. The aggravated form of the offence, therefore, could be seen as a conduct crime. $\mathrm{D}$ is subject to a maximum of life imprisonment where D commits criminal damage, having foreseen the risk of doing so, and in doing so is reckless as to the endangerment of others. D has already chosen to conduct himself in a certain manner, conscious (since $R v . G$ ) of the risk that exists with regards to property belonging to another. To choose to damage property is one thing, but if $\mathrm{D}$ decides to do so $\mathrm{D}$ should go about it in such a way that it does not risk bringing about a more serious harm: that of causing death. Thus, given that the offence under s.1(2) can be seen in this way to be a conduct crime, rather than a result crime, it would not be unreasonable to suggest that a different meaning should be attributed to "reckless" in this context. In this case the particular conduct is unlawful, but in essence $\mathrm{D}$ is being punished more harshly because of the way D goes about it and the more harmful risk that is created.

Under this analysis, criminal damage under s.1(2) would require two interpretations of "being reckless": subjective recklessness in relation to the result element of the offence (causing damage) and objective recklessness in relation to the conduct element of the offence 
(endangering others). In terms of statutory interpretation it could be argued that the parliamentary drafters could not have meant for these different meanings to be attributed to "being reckless" within the different subsections, and that had they wished for the alternative meanings to apply they would have utilised different terminology. However, the argument here is not that "reckless" or "recklessly" appearing in statute should be interpreted to mean different things, but that we need to look at the underlying nature of the offence to determine if it is D's conduct that D is being punished for, or whether it is his state of mind in relation to a proscribe harm that has resulted. Where a conduct crime has utilised the term "reckless" within its definition, this would suggest that it ought not to be interpreted as requiring subjective Cunningham recklessness and that the offence may need redrafting.

An example of this is the offence of rape. Rape is a conduct crime, since it penalises those who engage in sexual intercourse without the consent of their partner, without requiring any particular result from the act. When a man wishes to have sexual intercourse with another person, it is incumbent on him to take care that his partner is consenting, and to address his mind to that matter, before engaging in the act. ${ }^{83}$ It is appropriate, therefore, that an objective form of mens rea be required for rape. Section 1 of the Sexual Offences Act 1956 defined the mens rea of the offence as being that $\mathrm{D}$ knew that the person does not consent to the intercourse or is reckless as to whether that person consents to it. This led to difficulties of interpretation in cases such as Pigg, ${ }^{84}$ where Caldwell recklessness was applied to the

\footnotetext{
${ }^{83}$ Herring and Madden Dempsey have argued that sexual penetration is in itself a prima facie wrong requiring justification: Madden Dempsey and Herring, “Why Sexual Penetration Requires Justification” (2007) 27 O.J.L.S. 467-491. It is not suggested here that one need go so far as accepting such a proposition in order to agree that those who choose to engage in sex must do so with care.

${ }^{84}$ [1982] 1 W.L.R. 762.
} 
offence, and Satnam and Kewal, ${ }^{85}$ where the Court of Appeal took a subjective approach allowing D to escape liability if he genuinely believed that his partner consented (even where it would have been obvious to the reasonable person that she did not consent), but would be convicted where he "could not care less" as to whether she was consenting. The shortcomings of such a test of mens rea for rape led to s.1 of the Sexual Offences Act 2003 omitting the requirement of recklessness and replacing it with a test of reasonable belief, a form of negligence. Arguably, the use of the term "reckless" within s.1 of the 1956 Act was always erroneous, and the problem has now been rectified.

The way in which rape is constructed as an offence has something in common with aggravated criminal damage under s.1(2) of the Criminal Damage Act. This is that mens rea is required in relation to two separate elements of the offence. In rape, D must intend to sexually penetrate the vagina, anus or mouth of another person; in aggravated damage D must intend or be reckless as to damaging property belonging to another. In rape, D must not reasonably believe that $\mathrm{V}$ consents to the penetration; in aggravated criminal damage $\mathrm{D}$ must be reckless as to endangering the life of another. These secondary requirements have been interpreted as being the relevant "surrounding circumstances" to the actus reus. ${ }^{86}$ Arguably this can be said of other conduct crimes. In relation to the old offence of making a misleading forecast under s.12 of the Prevention of Fraud (Investments) Act 1939 the relevant "surrounding circumstances" to the making of a statement is that it be "misleading, false or

\footnotetext{
${ }^{85}$ (1984) 78 Cr.App.R. 149.

${ }^{86}$ See, for example, Clarkson, Keating and Cunningham, Clarkson and Keating Criminal Law: Text and Materials, $6^{\text {th }}$ ed. (London: Sweet and Maxwell), 2007.
} 
deceptive". The offence can be seen as a conduct crime and it is appropriate that an objective test be applied. ${ }^{87}$

Examples of conduct crimes (reckless driving, child neglect, rape, aggravated criminal damage) all involve the creation of risks. But all of these activities are in themselves hazardous occupations if not carried out with care. The underlying risk is always present, in that: driving is inherently dangerous; ${ }^{88}$ caring for a child can easily end in tragedy if sufficient attention is not paid to the child's needs; there is the possibility of interfering with another individual's autonomy; damage to property can easily create danger of at least injury to others. Psychologists suggest that there is a fundamental distinction between "risk and hazard".

"Risk" (in any sense) is a measure of a subjective process. "Hazard" is a measure of what actually happens independently of any subjective considerations. Strictly speaking, no individual is in a position to compare, in advance of any enterprise, the risk he is taking with the hazard the undertaking involves. The individual can only compare his risk (i.e. his expected success or failure) with his impression or guess of the hazard, or with past hazards. ${ }^{89}$

\footnotetext{
${ }^{87}$ On this basis, it is suggested that the decision in Large v. Mainprize [1989] Crim.L.R. 213 regarding the meaning of recklessness for the purposes of the offence of recklessly furnishing false information as to a catch of fish was wrong. In that case Cunningham subjective recklessness was held to apply, despite the court's approval of the objective test in Bates.

${ }^{88}$ Mitchell, "More Thoughts about Unlawful and Dangerous Act Manslaughter and the One-punch Killer" [2009] Crim LR 502 at 505.

${ }^{89}$ Cohen and Christensen, Information and Choice, (Edinburgh: Oliver and Boyd), 1970), p.101.
} 
If someone is engaging in hazardous conduct where the potential for risk exists, the question of whether she has foreseen that a risk might materialise is not relevant. The salient point is that she must take care in engaging in the activity to try to minimise the possibility of the potential risk occurring. If she fails to take sufficient care, creating a risk from a hazardous situation, she becomes blameworthy, whether or not she adverts to the risk. She has carried out the hazardous activity in a reckless manner if she fails to take care, thereby creating a risk which should have been avoided.

An objective test of mens rea is appropriate in relation to conduct crimes, because D is partaking in a dangerous activity and so should pay attention to the risks and is blameworthy if she does not. D ought to make her knowledge of a risk "explicit", to use another term employed by Duff, ${ }^{90}$ by making herself alert to the potential risks involved in the activity and calling her latent knowledge to mind. If she fails to do so she is blameworthy and should attract criminal condemnation. On the other hand, in relation to result crimes we start from the position that a particular proscribed harm has been caused and need to work our way back from there in order to determine whether D's state of mind is sufficiently blameworthy in relation to that harm in order to attract criminal liability. A different test is appropriate to that employed in relation to conduct crimes.

If this distinction had not been rejected the law may have taken a different course, and although it was rejected by legal authority, others supported the distinction. In his commentary of Murphy Smith commented that the test laid down in that case was one of

\footnotetext{
${ }^{90}$ See Duff, above n.77, p.80.
} 
negligence, and opined that " $[\mathrm{t}]$ he present case applies a peculiar notion of recklessness and it does not follow that it should be applied in 'result crimes"'. ${ }^{91}$ In Elliott v. C, Goff L.J. said:

This is a case where it appears that the only basis upon which the accused might be held to have been reckless would be if the appropriate test to be applied was purely objective - a test which might in some circumstances be thought justifiable in relation to certain conduct (e.g. reckless driving), particularly where the word 'reckless' is used simply to characterise the relevant conduct. But such a test does not appear at first sight to be appropriate to a crime such as that under consideration in the present case, especially as recklessness in that crime has to be related to a particular consequence. ${ }^{92}$

Notwithstanding this, Lord Goff felt bound by precedent to find that there was recklessness in this case, as he could not depart from the test laid down by the House of Lords in Caldwell.

Now that reckless driving has been replaced by dangerous driving the problem of ensuring that culpability in driving offences concentrates on the manner in which the activity of driving is carried out, rather than on the state of mind of the driver at the time of the creation of a risk, has been resolved. There remain, however, a few offences in relation to which it is not clear whether subjective recklessness or some other form of mens rea applies. Following the above discussion, it is submitted that in deliberating this question, a specific definition of recklessness should apply to result crimes such as offences against the person and non-aggravated criminal damage, whilst in relation to conduct crimes a different, more objective test is appropriate.

\footnotetext{
${ }^{91}$ [1980] Crim LR 309 at p.312.

92 (1983) 77 Cr App R 103 at 118.
} 
The judges in the House of Lords in $R v G$ were careful to restrict their judgment to the meaning of recklessness in relation to criminal damage, seemingly leaving other offences unaffected. However, as we have seen, Caldwell/Lawrence recklessness was already redundant in relation to driving offences, leaving few other offences to which it had ever been applied. Two such offences were acting recklessly in a manner likely to endanger an aircraft or persons therein and recklessly causing or permitting an aircraft to endanger persons or property. ${ }^{93}$ These are clearly conduct crimes to which the subjective Cunningham test of recklessness should not be applied, since they can be likened to reckless driving.

As was seen above, another offence which has applied a more "objective" test of recklessness than that laid down in Cunningham is wilful neglect of a child. The test in Sheppard was different to that laid down in relation to reckless driving in Murphy, however, since it allowed for inquiry into the reason behind a lack of appreciation of the risk to the child. Lord Keith of Kinkel state that:

A parent who fails to provide medical care which his child needs because he does not care whether it is needed or not is reckless of his child's welfare. ... But a parent who has genuinely failed to appreciate that his child needs medical care, through personal inadequacy or stupidity or both, is not guilty. ${ }^{94}$

Has this test of mens rea for child neglect survived $R v G$ ? Despite Lord Bingham confining his decision in $R v G$ to the offence of criminal damage, the Court of Appeal in Attorney General's Reference (No.3 of 2003) $)^{95}$ stated that: "Clearly the labelling of

\footnotetext{
${ }^{93}$ Warburton-Pitt (1991) 92 Cr App R 136.

${ }^{94}$ Above n.37 at p.99.

95 [2004] 2 Cr App R 23.
} 
recklessness as 'Cunningham recklessness' or 'Sheppard recklessness' is overtaken by the decision in $G " .{ }^{96}$ It is not at all clear that this is an accurate statement. If Lord Bingham was unwilling to create an overarching rule in relation to recklessness it is likely that this reluctance stems from the need to consider the appropriate mens rea requirement in relation to any particular offence, depending on the mischief the offence is designed to deter.

In $A G$ 's Reference itself the offence in question was the common law offence of misconduct in public office. The defendants in the case were police officers whose prisoner had died whilst in their custody, and they had been charged with gross negligence manslaughter and misconduct in public office in the alternative. There was an issue with causation meaning that the offence of manslaughter was not made out, but the question then became what the mens rea for misconduct in public office would be.

Counsel for the Attorney General argued that misconduct in public office is a conduct crime and not a result crime, and that there has been misconduct by $\mathrm{D}$ if he is indifferent as to whether the acts or omissions constituting the misconduct may have had any consequences. In making these arguments, counsel sought to rely on Sheppard to support the claim that this species of objective recklessness would be a valid form of mens rea in a case involving a "duty situation". It would seem that counsel made a valid point here. Where a duty to others arises, either because D is V's parent or by virtue of D's occupation, D should not escape liability because he is "callous" and failed to advert to what his responsibilities were and to the risk of harm to particular individuals (D's child or a person within D's care). In the event the Court of Appeal rejected counsel's submissions and ruled that the test was one of

96 At [29]. 
subjective recklessness, both as to the existence of a duty and the conduct of the defendant. ${ }^{97}$ It is submitted that the court's decision is erroneous and that, contrary to what was suggested in this case, $R v G$ has no effect on either the offence of child neglect or the offence of misconduct in public office and that as these offences are conduct crimes seeking to punish those who fail to live up to a standard of care incumbent upon them, a different test to that applicable to result crimes ought to be applied.

The way in which blameworthiness should be attributed in relation to result crimes, on the one hand, and conduct crimes, on the other, reflects the distinction between the capacity conception and the normative conception of mens rea. ${ }^{98}$ Cognitive mens rea requires either intention to cause a result or foresight of that result, whilst normative mens rea involves ensuring that the "mens was rea". ${ }^{99}$ Under the normative conception, the defendant's actions must be evaluated, taking into account all the circumstances and not only what was going on in the defendant's mind. Whilst some might argue that the normative and cognitive conceptions of mens rea are incompatible with one another, the argument here is

\footnotetext{
${ }^{97}$ The court's ruling on this point is rather perplexing. The mens rea of the offence is stated as follows: "There must be an awareness of the duty to act or a subjective recklessness as to the existence of the duty. The recklessness test will apply to the question whether in particular circumstances a duty arises at all as well as to the conduct of the defendant if it does. The subjective test applies both to reckless indifference to the legality of the act or omission and in relation to the consequences of the act or omission" (at [30]). Given that this is a conduct crime and no consequences are required in order that the offence be proved this last sentence appears nonsensical.

98 Clarkson, Keating and Cunningham, Clarkson and Keating Criminal Law: Text and Materials $6^{\text {th }}$ ed. (London: Sweet and Maxwell) 2007, p.115.

99 Amirthalingam, “Caldwell Recklessness is Dead, Long Live Mens Rea’s Fecklessness” (2004) 67 MLR 491 at 492 .
} 
that they both have their place within the criminal law. One is appropriate for result crimes; the other for conduct crimes.

One criticism that could be levelled at the employment of normative mens rea, or an objective form of recklessness, is that it might be seen as breaching Ashworth's principle of correspondence. ${ }^{100}$ This requires that D's mens rea relates to the proscribed harm of the offence in question. A result crime such as non-aggravated criminal damage under s.1(1) of the Criminal Damage Act adheres to the principle by requiring D to foresee the particular proscribed harm of damage to property belonging to another. If the above suggestion were to be taken on board, the same would not be true of aggravated criminal damage under s.1(2) of the Criminal Damage Act, since D could be held liable for the more serious offence even if she did not foresee that she might endanger the lives of others by damaging property. However, Tadros has argued that the correspondence principle, while requiring that the harm with which the offence is concerned is included in the fault element of the offence, does not limit what the fault element might be. ${ }^{101}$ As long as D ought to have been aware of the risk of the proscribed harm or the harm with which the offence is concerned, the principle of correspondence need not be breached. Thus, an objective test of mens rea applying to conduct crimes should include within its requirements a reference to the harm that the conduct crime is seeking to prevent. For example, dangerous driving is defined by reference to the fact that the driving must have created a danger of injury to any person or of serious damage to property. ${ }^{102}$ D's negligence in falling far below the standard of the competent and careful driver must be measured with this in mind. Given that the harm that dangerous

\footnotetext{
${ }^{100}$ Ashworth, Principles of Criminal Law, $6^{\text {th }}$ ed. (Oxford: OUP) 2009, p.76.

101 Tadros, Criminal Responsibility (Oxford: OUP) 2005, p.95.

${ }^{102}$ Road Traffic Act 1988, s.2A(3).
} 
driving seeks to prevent is primarily the causing of injury to other road users, the law does not breach the principle of correspondence. ${ }^{103}$

However, the correspondence principle does highlight problems with constructive crimes created by taking a conduct crime and introducing a more serious offence where a particular result occurs. An example would be causing death by dangerous driving. Whilst it may be argued that dangerous driving itself does not breach the principle of correspondence, provided that Tadros' point above is accepted, the same cannot be said of the offence of causing death by dangerous driving under s. 1 of the Road Traffic Act 1988. This requires no further mens rea in relation to death or the creation of a risk of death than does the conduct crime under s.2, and therefore breaches the principle of correspondence. To rectify this, the law would have to require that driving was to be deemed dangerous if it created a risk of death, not just injury. ${ }^{104}$ However, more to the point, because causing death by dangerous driving is a result crime it should, according to the arguments presented here, involve a different (more subjective) test of mens rea.

The causing death by driving offences are not the only homicide offences which do not sit well with the foregoing thesis that one form of recklessness applies to result crimes and a different form of mens rea, probably best described as gross negligence, applies to conduct crimes. Involuntary manslaughter is a result crime, the mens rea for which can be

\footnotetext{
${ }^{103}$ Although it may be argued that the test under s.2A(3) should be limited to the creation of a danger of injury to people and not extend to the risk of serious damage to property.

${ }^{104}$ If it did so, there would be virtually nothing to separate it from the general offence of manslaughter, however. See Cunningham, "Vehicular Homicide: Need for a Special Offence?" in Clarkson and Cunningham, Criminal Liability for Non-Aggressive Death (Aldershot: Ashgate) 2008, p.110.
} 
satisfied through proof of gross negligence. ${ }^{105}$ It may be that my analysis suggests that the law is wrong to punish for manslaughter those who engage in lawful activity but who cause death by failing to live up to the standard expected of them. Such a view would be controversial on policy grounds, although some might be supportive of it. Quick has argued in the context of medical killings, for example, that gross negligence ought to be abolished and reliance placed on reckless manslaughter. ${ }^{106}$

If we were to try to find accordance with the thesis I have presented here, we could argue that when $\mathrm{D}$ is convicted of gross negligence manslaughter $\mathrm{D}$ is punished for death resulting from the way in which D carried out a particular activity, rather than for his state of mind relating to the possibility of a particular consequence (death). To use the distinction applied earlier, if we were to revert to using the word "reckless" (rather than grossly negligent) to describe the nature of the blameworthiness in a doctor causing his patient to die through his act or, more often, by his omission, we would use "reckless" as an adverb describing his actions in treating his patient and his failure to take sufficient care, rather than as an adjective describing the consequences of his treatment. Arguably this is the way in which Lord Mackay wanted the word "reckless" to be used in directions to the jury in cases of gross negligence manslaughter. ${ }^{107}$ This also fits in with the arguments put forward by counsel in $A G$ 's Reference (No.3 of 2003): where D is blameworthy because he has breached

${ }^{105}$ It should be noted that, unlike the offence of causing death by dangerous driving, gross negligence manslaughter could be seen, from an objectivist's viewpoint, not to breach the principle of correspondence, since the test under Adomako requires that the jury have regard to the risk of death involved.

${ }^{106}$ Quick, “Medical Killing: Need for a Special Offence?” in Clarkson and Cunningham, Criminal Liability for Non-Aggressive Death (Aldershot: Ashgate) 2008.

${ }^{107}$ Adomako, n.32 above at 187. 
a duty of care owed to $\mathrm{V}$ then it is appropriate that an objective test be applied. The problem with such an argument, however, is that it does not explain why D is held liable for the resulting death rather than for his conduct (grossly negligent treatment of a patient, for example). If the above thesis is accepted, it must be recognised that manslaughter, as it is currently defined, does not fit the dichotomy between result crime and conduct crime.

That being the case, it may be that we must agree with Quick that manslaughter ought to require a more subjective test of mens rea. This would be contrary to the orthodox position, including that of the Law Commission in its recommendations relating to reform of the law of manslaughter. ${ }^{108}$ Maybe it is inevitable that the law relating to homicide will always undermine a number of principles of criminal law, including the principle of correspondence, as it is seen differently to other result crimes. Fletcher emphasises the uniqueness of homicide, suggesting that the starting point for determining criminal liability is different to that of other harms:

What makes homicide unique is, among other things, the uniqueness of causing death. While all personal injuries and destruction of property are irreversible harms, causing death is a harm of a different order. Killing another human being is not only a worldly deprivation; in the Western conception of homicide, killing is an assault on the sacred, natural order. ${ }^{109}$

Fletcher later explores the implications of this:

\footnotetext{
${ }^{108}$ Law Commission for England and Wales (Law Com. No.304). Murder, Manslaughter and Infanticide (2006)

${ }^{109}$ Fletcher, Rethinking Criminal Law (Oxford: Oxford University Press) 2000, p.235.
} 
There are three prominent starting places for thinking about criminal liability. In the pattern of manifest criminality, the point of departure is an act that threatens the peace and order of community life. In the theory of subjective criminality, the starting place is the actor's intent to violate a protected legal interest. In the law of homicide, the focal point is neither the act nor the intent, but the fact of death. This overpowering fact is the point at which the law begins to draw the radius of liability. From this central point, the perspective is: who can be held accountable, and in what way, for the desecration of the human and divine realms? The question is never where to place the point of the legal compass, but how far the arc should sweep in bringing in persons to stand responsible for the death that has already occurred ${ }^{110}$

If the above thesis were to be accepted outright, the suggestion would be that the arc of the legal compass should sweep only so far as defendants who advert to the risk of death, if they are to be held liable for the result crime of manslaughter. Even if that were the case, however, in practice liability for those such as surgeons who perform their duty in a grossly negligent manner would remain dependant on an objective test of liability. ${ }^{111}$ Highly trained surgeons realise that, when they undertake to operate on a patient under general anaesthetic, a risk of death exists. ${ }^{112}$ Thus, in applying the subjective Cunningham test of recklessness, the first part of the test (did D recognise the risk?) would always be met. Liability would therefore depend upon how the second part of the Cunningham test was answered: was it unreasonable for $\mathrm{D}$ to take that risk having regard to the circumstances as he knows or

\footnotetext{
${ }^{110}$ Ibid, p.341.

${ }^{111}$ This is a potential criticism of Quick's thesis which he himself recognises: Quick, above .n.106, p.165.

${ }^{112}$ Quick makes a similar point in his discussions: Quick, above n.106, p.164.
} 
believes them to be? This is practically the same question that is asked when applying an objective test of recklessness.

Quick's solution is to endorse Tadros' suggestion of a "middle way" between subjective and objective requirements. ${ }^{113}$ So long as human nature, due to the uniqueness of homicide, sees fit to punish those whose mistakes cause death, with such punishment satisfying emotional rather than rational purposes, it would seem that this compromise could be the best option for providing a mens rea requirement for an offence which does not sit neatly within the result crime/conduct crime dichotomy.

\section{Conclusion}

This paper has argued that the law of recklessness developed two different meanings over the course of time, and that problems were caused when the House of Lords attempted to apply objective recklessness, developed from case law relating to which used "recklessness" as a way of defining the degree of negligence warranting criminal sanction, to a crime where the appropriate use of the word "reckless" was as an alternative to "malice". It is perhaps ironic that the one offence which first used the term "recklessly" in statute has been reformed to apply instead a clear test of negligence (dangerous driving). However, it is quite right that negligence is the appropriate test for that and other conduct crimes or regulatory offences, and that recklessness proper should apply to result crimes.

113 Quick, above n.106, p.165, quoting Tadros, "Recklessness and the Duty to Take Care" in Shute and Simester, Criminal Law Theory: Doctrine of the General Part (Oxford: OUP) 2002, p.258. Tadros' test is as follows: (a) the action was of a kind that might carry risks with it according to the beliefs of the individual; and either (bi) given those beliefs the agent failed to fulfil his duty of investigating the risks; or (bii) the agent willfully blinded himself to the existence of the risks. 
The dichotomy between result crimes and conduct crimes could be a useful tool for determining the appropriate form of mens rea to apply in relation to cases where there remains a question mark over the application of $R v G$, or where existing offences are reformed or new offences created in order to provide a more rational and coherent structure to the specific part of the criminal law. "Recklessness", where it is already in use in statute, does not necessarily have to mean the same thing in all contexts. Where law is reformed, the examples set by the Sexual Offences Act 2003 and the Road Traffic Act 1991 ought to be followed in using appropriate terminology to define the blameworthiness of defendants in objective terms for conduct crimes, without the confusion brought by using "reckless" to describe the degree of negligence required. With regards to result crimes, the presumption ought to be that the term "reckless" requires advertence to a risk. This might have a radical impact on the criminal law, particularly in relation to homicide offences, but is one that ought to be welcomed. 